\title{
ANALISIS FAKTOR-FAKTOR YANG MEMPENGARUHI RETURN SAHAM PADA PERUSAHAAN MAKANAN DAN MINUMAN (FOOD AND BEVERAGES) YANG TERDAFTAR DI BURSA EFEK INDONESIA (BEI) TAHUN 2015 - 2018
}

\author{
Junnei Liuspita \\ Program Studi Magister Manajemen Universitas Tarumanagara \\ jliuspitaa@gmail.com \\ Indra Widjaja \\ Program Studi Magister Manajemen Universitas Tarumanagara
}

Masuk : 28-05-2020, revisi : 24-06-2020 diterima untuk diterbitkan : 24-06-2020

\begin{abstract}
Abstrak : This research aims to find out the influence of Return on Assets (ROA), Return on Equity (ROE), Net Profit Margin (NPM), Debt to Equity Ratio (DER), Earning Per Share (EPS) on the stock return of food and beverage companies listed in the Indonesia Stock Exchange for the period 2015 to 2018 . The research sample consists of 13 companies, that were selected by using a purposive technique sampling method for the period of 2015-2018. The method to analyse the research questions was by using the statistical method of multiple linear regression method. The result found that Return on Assets (ROA), Return on Equity (ROE) have significant influences on the stock return. Whilst aNet Profit Margin (NPM), Debt to Equity Ratio (DER), and Earning Per Share (EPS) partially don't have significant influence. The coefficient determination of this model was found to be about only $28,17 \%$. This suggests that the five independent variables underestimated have a lack of explanatory power of the stock return of food and beverage companies. Hence, further studies to seek other independent variables in the model are suggested to improve the model underestimated.
\end{abstract}

Abstrak : Tujuan dari penelitian ini adalah untuk mengetahui pengaruh Return on Assets (ROA), Return on Equity (ROE), Net Profit Margin (NPM), Debt to Equity Ratio (DER), Earning Per Share (EPS) terhadap return saham perusahaan makanan dan minuman yang terdaftar di Bursa Efek Indonesia untuk periode 2015 hingga 2018. Sampel penelitian, terdiri dari 13 perusahaan, dipilih dengan menggunakan metode teknik purposive sampling dengan periode penelitian 2015-2019. Metode untuk menganalisis pertanyaan penelitian adalah dengan menggunakan metode statistik regresi linier berganda. Hasil penelitian menemukan bahwa, Return on Assets (ROA), Return on Equity (ROE), secara parsial berpengaruh signifikan terhadap return saham. Sementara Net Profit Margin (NPM), Debt to Equity Ratio (DER), Earning Per Share (EPS) secara parsial tidak memiliki pengaruh yang signifikan. Koefisien determinasi model ini hanya $28,17 \%$. Ini menunjukkan bahwa kelima variabel independen tersebut memiliki kurangnya pengaruh terhadap harga saham perusahaan makanan dan minuman. Oleh karena itu, penelitian lebih lanjut untuk mencari variabel independen lain yang dapat meningkatkan pengaruh terhadap harga saham yang tidak diestimasi dalam model ini

Keywords : Return on Assets (ROA), Return on Equity (ROE), Net Profit Margin (NPM), Debt to Equity Ratio (DER), Earning Per Share (EPS), Return Saham

\section{PENDAHULUAN}

Berdirinya suatu perusahaan tidak terlepas dari peran investor, melihat keadaan perekonomian yang tidak selalu stabil, berinvestasi adalah salah satu langkah strategis yang bisa dilakukan setiap orang untuk menghasilkan uang lebih. Kepentingan utama pemegang saham adalah kembalinya produktivitas perusahaan, dalam hal ini dividen dan apresiasi saham. 
Pengembalian saham pasar dianggap sebagai faktor kunci dalam memilih peluang investasi terbaik. Kenaikan return saham industri makanan dan minuman tersebut menarik untuk dikaji lebih lanjut faktor penyebabnya. Perusahaan food and Baverage merupakan salah satu dari pelaku bisnis di Bursa Efek Indonesia (BEI) yang bergerak di bidang barang konsumsi dan memiliki peran penting dalam pertumbuhan perekonomian indonesia.

\section{Tujuan Penelitian}

Tujuan dari penelitian ini adalah untuk mengetahui pengaruh Return on Assets (ROA), Return on Equity (ROE), Net Profit Margin (NPM), Debt to Equity Ratio (DER), Earning Per Share (EPS) terhadap return saham perusahaan makanan dan minuman yang terdaftar di Bursa Efek Indonesia untuk periode 2015 hingga 2018 baik secara parsial maupun bersama-sama.

\section{TELAAH KEPUSTAKAAN}

Return saham adalah tingkat keuntungan yang dinikmati oleh pemodal atas suatu investasi saham yang dilakukan. Tujuan investor dalam berinvestasi adalah untuk meningkatkan nilai kekayaan dengan cara memaksimalkan return tanpa melupakan faktor risiko yang dihadapinya (Aryanti, 2015: 57). Menurut Saragih (2018: 350) menjelaskan bahwa semakin tinggi rasio ini berarti perusahaan lebih efektif dalam menggunakan aset untuk menghasilkan batas pemasukan. Dengan demikian semakin tinggi ROA berarti kinerja perusahaan semakin efektif karena tingkat pengembalian akan lebih besar. Sedangkan Return on Equity (ROE) mengukur kemampuan perusahaan untuk memberikan pengembalian bagi pemegang saham dan didefinisikan sebagai dividen dalam laba bersih atas kepemilikan saham (Asmirantho dan Somantri, 2017: 96). Menurut Rusdiyanto et al (2018: 1502), suatu bank akan menentukan apakah bank sehat, mengingat ini, manajemen manajemen bank menjadi hebat perhatian dalam menilai kesehatan bank, bank diharapkan dapat menciptakan dan menjaga kesehatan, menilai aspek rasio Net Profit Margin (NPM). Rasio Hutang terhadap Ekuitas (DER) adalah kemampuan untuk memenuhi kekurangan dan kekurangan perusahaan kewajiban jangka panjang (Putra et. Al, 2017: 134). Menurut Putra dan Kindangen (2016: 237), Earning Per Share (EPS) merupakan salah satu rasio yang sering digunakan dalam laporan tahunan kepada pemegang saham yang merupakan laba bersih dikurangi dividen dibagi dengan rata-rata tertimbang dari saham biasa yang beredar akan menghasilkan laba per saham.

\section{KERANGKA PEMIKIRAN}

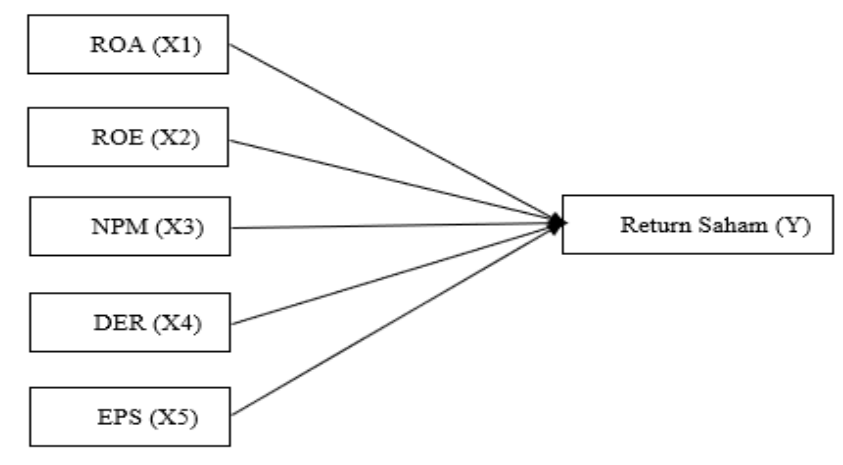

Figure 1: Kerangka Pemikiran

\section{Gambar 1}

\section{Kerangka Pemikiran}

H1: Return on Asset (ROA) berpengaruh terhadap Return saham.

H2: Return on Equity (ROE) berpengaruh terhadap Return saham

H3: Net Profit Margin (NPM) berpengaruh terhadap Return saham

H4: Debt to Equity Ratio (DER) berpengaruh terhadap Return saham

H5: Earning Per Share (EPS) berpengaruh terhadap Return saham 


\section{METODE PENELITIAN}

Penelitian ini bersifat kuantitatif dikarenakan jenis data yang digunakan dalam penelitian ini adalah data kuantitatif berupa laporan keuangan dan profil perusahaan makanan dan minuman pada Bursa Efek Indonesia (BEI). Pengambilan sampel dalam penelitian ini adalah dengan menggunakan metode purposive sampling, yaitu metode pengambilan sampel dengan menggunakan kriteria - kriteria tertentu. 13 perusahaan yang telah lolos kriteria-kriteria dijadikan sampel. Pengujian dasar adalah untuk melakukan regresi atas variabel terikat dengan variabel bebas. Adapun model regresi pada penelitian ini adalah sebagai berikut:

$$
Y=\alpha+\beta 1 . X 1 t+\beta 2 . X 2 t+\beta 3 . X 3 t+\beta 4 . X 4 t+\beta 5 . X 5 t+\beta 6 . X 6 t+e
$$

Dimana:

$$
\begin{aligned}
& \mathrm{Y}=\text { Return } \text { Saham } \\
& \alpha=\text { Konstanta (intercept) } \\
& \mathrm{X} 1=\text { Return on Assets }(\text { ROA }) \\
& \mathrm{X} 2=\text { Return on Equity }(\text { ROE }) \\
& \mathrm{X} 3=\text { Net Profit Margin }(\text { NPM }) \\
& \mathrm{X} 4=\text { Debt to Equity Ratio }(\text { DER) } \\
& \mathrm{X} 5=\text { Earning Per Share }(\mathrm{EPS})
\end{aligned}
$$

HASIL DAN PEMBAHASAN

Hasil Uji Hipotesis

Tabel 1

\section{Hasil Uji t}

\begin{tabular}{crrrr}
\hline \hline Variable & Coefficient & Std. Error & t-Statistic & Prob. \\
R & 0.107923 & 0.149353 & 0.722608 & 0.4736 \\
ROA & 0.035099 & 0.009085 & 3.863447 & 0.0003 \\
NPE & 0.007146 & 0.003289 & 2.172592 & 0.0350 \\
DER & -0.041209 & 0.011111 & -3.708943 & 0.0006 \\
EPS & -0.000778 & 0.001408 & -0.552304 & 0.5834 \\
\hline \hline
\end{tabular}

Sumber: Hasil pengolahan data dengan Eviews

Uji T untuk menguji pengaruh secara parsial terhadap variable dependen, dan juga untuk mengetahui pengaruhnya signifikan atau tidak. Uji $t$ ini menggunakan nilai signifikansi 0.05 atau 5\%. Berikut hasil mengenai pengaruh dari masing-masing variabel independen terhadap variabel dependen dalam penelitian ini berdasarkan hasil pengujian diatas:

1. Return on assets berpengaruh secara positif dan signifikan terhadap return saham.

2. Return on Equity berpengaruh secara positif dan signifikan terhadap return saham.

3. Net Profit Margin berpengaruh negatif dan signifikan terhadap return saham.

4. Debt to Equity Ratio tidak berpengaruh signifikan terhadap return saham.

5. Earnings Per Share tidak berpengaruh signifikan terhadap return saham

\section{Tabel 2}

\section{Hasil Uji F}

\begin{tabular}{llr}
\hline \hline R-squared & $\mathbf{0 . 2 8 1 7 4 0}$ Mean dependent var & 0.089231 \\
Prob(F-statistic) & $\mathbf{0 . 0 0 7 7 5 8}$ & \\
\hline \hline
\end{tabular}

Sumber: Hasil pengolahan data dengan Eviews

Hasil menunjukkan hasil uji $\mathrm{F}$ memiliki nilai signifikansi sebesar 0.007758. Nilai tersebut lebih kecil dari 0,05 sehingga dapat disimpulkan bahwa model fit bahwa variabel independen dapat memprediksi variabel dependen dan layak digunakan dalam penelitian. Hasil pengujian menunjukkan nilai $R$-Squared sebesar $28.1740 \%$ dan sisanya lagi $71,8260 \%$ dipengaruhi oleh faktor-faktor lain yang tidak dimasukkan dalam model. 


\section{KESIMPULAN}

Berdasarkan analisis dan pembahasan yang dilakukan terhadap 13 perusahaan makanan dan minuman yang terdaftar di Bursa Efek Indonesia (BEI) periode 2015-2018 dapat menyimpulkan bahwa Return on Equity dan berpengaruh positif dan signifikan terhadap Return saham. Berdasarkan hasil analisis tersebut, maka investor mempertimbangkan tingkat ROA dan ROE yang dicapai oleh perusahaan, sehingga investor bersedia membayar saham perusahaan dengan harga yang lebih tinggi ketika ROA yang dihasilkan perusahaan juga tinggi. NPM berpengaruh negatif dan signifikan terhadap return saham. Hal ini berarti setiap kenaikan NPM akan menyebabkan penurunan return saham. Apabila perusahaaan tidak mampu menghasilkan keuntungan bagi perusahaan sehingga mempengaruhi investor maupun calon investor untuk melakukan investasi. DER dan EPS berpengaruh tidak signifikan terhadap return saham. Hasil penelitian ini menunjukan bahwa informasi perubahan DER dan EPS yang diperoleh dari laporan keuangan tidak berpengaruh pada keputusan atas harga saham dipasar modal Indonesia.

\section{DAFTAR PUSTAKA}

Aryanti \& Mawardi (2016). Pengaruh ROA, ROE, NPM dan CR terhadap Return Saham pada Perusahaan yang Terdaftar di Jakarta Islamic Index (Jii). I-Finance, 2 (2), 54-71.

Asmirantho, E., \& Somantri, O. K. (2017). The Effect of Financial Performance on Stock Price at Pharmaceutical Sub-Sector Company Listed in Indonesia Stock Exchange. JIAFE (Jurnal Ilmiah Akuntansi Fakultas Ekonomi), 3 (2), 94-107.

Putra, F. E. P. E., \& Kindangen, P. (2016). Pengaruh Return on Asset (ROA), Net Profit Margin (NPM), dan Earning Per Share (EPS) terhadap Return Saham Perusahaan Makanan dan Minuman yang Terdaftar di Bursa Efek Indonesia (Periode 2010-2014). Jurnal Riset Ekonomi, Manajemen, Bisnis dan Akuntansi, 4 (3), 235-245.

Putra, F. L., Nurlaela, S., \& Samrotun, Y. C. (2017). Effect of Return on Asset, Return on Equity, Debt to Equity Ratio to Return Stock Company Property and Real Estate in Indonesia Stock Exchange. Technology, Education and Social Sciences, 1 (1), 133-140.

Rusdiyanto, Soetedjo, S., Susetyorini, \& Elan, U. (2019). The Effect of Capital Adequacy Ratio (CAR), Net Profit Margin (NPM), Return on Assets (ROA), Non-Performing Loans (NPL) and Loan to Deposit Ratio (LDR) to Stock Prices in Banking Companies on the Indonesia Stock Exchange, 8 (7), 1499-1510.

Saragih, J. L. (2018). The Effects of Return on Assets (ROA), Return on Equity (ROE), and Debt to Equity Ratio (DER) on Stock Returns in Wholesale and Retail Trade Companies Listed in Indonesia Stock Exchange. International Journal of Science and Research Methodology, 8 (3), 348-367. 